\section{Increased Fertilizer Levels Do Not Prevent Abscisic Acid-Induced Chlorosis in Pansy}

\author{
Jong-Goo Kang ${ }^{1}$, Rhuanito Soranz Ferrarezi ${ }^{2}$, Sue K. Dove ${ }^{3}$, \\ Geoffrey M. Weaver ${ }^{3}$, and Marc W. van Iersel $^{3,4}$
}

AdDitional INDEX wORDs. ABA, chlorophyll, controlled-release fertilizer, stomatal closure, Viola $\times$ wittrockiana

Summary. Abscisic acid (ABA) is a plant hormone involved in regulating stomatal responses to environmental stress. By inducing stomatal closure, applications of exogenous $\mathrm{ABA}$ can reduce plant water use and delay the onset of drought stress when plants are not watered. However, ABA can also cause unwanted side effects, including chlorosis. Pansy (Viola $\times$ wittrockiana) has been shown to be particularly susceptible to ABA-induced chlorosis. The objective of this study was to determine if fertilization rate affects the severity of $A B A$-induced chlorosis in this species. 'Delta Premium Pure Yellow' pansy seedlings were fertilized with controlled-release fertilizer incorporated at rates from 0 to $8 \mathrm{~g} \cdot \mathrm{L}^{-1}$ of substrate. When plants had reached a salable size, half the plants were sprayed with a solution containing $1 \mathrm{~g} \cdot \mathrm{L}^{-1} \mathrm{ABA}$, whereas the other plants were sprayed with water. Leaf chlorophyll content was monitored for 2 weeks following ABA application. Leaf chlorophyll content increased greatly as fertilizer rate increased from 0 to $2 \mathrm{~g} \cdot \mathrm{L}^{-1}$, with little increase in leaf chlorophyll at even higher fertilizer rates. ABA induced chlorosis, irrespective of the fertilizer rate. Plant dry weight was lowest when no controlledrelease fertilizer was incorporated, but similar in all fertilized treatments. ABA treatment reduced shoot dry weight by $\approx 24 \%$, regardless of fertilization rate. This may be due to ABA-induced stomatal closure, which limits carbon dioxide $\left(\mathrm{CO}_{2}\right)$ diffusion into the leaves. We conclude that ABA sprays induce chlorosis, regardless of which fertilizer rate is used. However, because leaf chlorophyll concentration increases with increasing fertilizer rates, higher fertilizer rates can mask ABAinduced chlorosis.

A bscisic acid is a hormone that has an important role in regulating stomatal closure. In response to drought stress, ABA can be synthesized in roots and translocated to leaves by way of the transpirational stream (Davies et al., 2005; Malladi and Burns, 2007), or produced within the leaves or shoots (Christmann et al., 2007; Galvez-Valdivieso et al., 2009). In leaves, ABA causes a reduction in stomatal aperture by triggering a signaling cascade that leads to the net movement of ions and water out of stomatal guard cells (Raghavendra et al., 2010). Abscisic acid may further regulate stomatal closure by lowering the hydraulic

This paper was supported by the Sunchon National University Research Fund in 2013. Abscisic acid was donated by Valent BioSciences Corporation.

${ }^{1}$ Department of Horticulture, Sunchon National University, Chonnam 540-742, South Korea

${ }^{2}$ Agricultural Experimental Station, University of the Virgin Islands, RR 1 Box 10,000, Kingshill, VI 00850

${ }^{3}$ Department of Horticulture, University of Georgia, 1111 Miller Plant Science Building, Athens, GA 30602

${ }^{4}$ Corresponding author. E-mail: mvanier@uga.edu.

doi: 10.21273/HORTTECH03441-16 conductivity of leaf vascular tissue (Pantin et al., 2012). The resultant stomatal closure allows plants to more effectively tolerate drought stress by limiting the amount of water lost through transpiration (Buckley, 2005; Kim et al., 2012).

For ornamentals, ABA is an effective way to extend shelf life. Plants treated with exogenous ABA can tolerate a temporary lack of watering with little or no wilting. Using ABA to extend the shelf life of ornamentals could be beneficial to growers, especially if their plants will spend an extended period in shipping and retailing, or if their distributors operate by the pay-by-scan system (Starman et al., 2007; van Iersel et al., 2009; Waterland et al., 2010a; Yue and Behe, 2008). Unfortunately, spray and drench applications of ABA have been shown to cause chlorosis in several plant species. This unwanted side effect could limit the usefulness of ABA as a commercial holding agent (Kim and van Iersel, 201 1; van Iersel et al., 2009; Waterland et al., 2010a; Weaver and van Iersel, 2014).

Nitrogen is an essential component of chlorophyll, and leaf nitrogen concentration correlates positively to leaf chlorophyll content (Evans, 1983; Loh et al., 2002). We hypothesized that increased fertilization can reduce the severity of ABA-induced chlorosis in pansy. Pansy was used as a model plant because previous research has shown that they are highly susceptible to chlorosis when treated with ABA sprays (Waterland et al., 2010a; Weaver and van Iersel, 2014).

\section{Materials and methods}

Greenhouse environment. This study was performed in a glasscovered greenhouse in Athens, GA, from 21 Oct. to 20 Dec. 2013. Greenhouse environmental conditions were measured using a quantum sensor for photosynthetic photon flux $(P P F)$ (SQ-110; Apogee Instruments, Logan, UT) and a temperature and relative humidity sensor (HMP50; Vaisala, Vantaa, Finland) connected to a datalogger (CR10; Campbell Scientific, Logan, UT). The vapor pressure deficit was calculated from the saturated and actual air vapor pressure, using the air temperature and relative humidity data. The daily light integral was calculated by integrating the $P P F$ measurements for each day. The daily average values, from the time of $A B A$ treatment (45 $\mathrm{d}$ after transplanting)

\begin{tabular}{llll}
\hline $\begin{array}{l}\text { Units } \\
\text { To convert U.S. to SI, } \\
\text { multiply by }\end{array}$ & U.S. unit & SI unit & $\begin{array}{l}\text { To convert SI to U.S., } \\
\text { multiply by }\end{array}$ \\
\hline 3.7854 & gal & $\mathrm{L}$ & 0.2642 \\
2.54 & inch $(\mathrm{es})$ & $\mathrm{cm}$ & 0.3937 \\
0.5933 & lb/yard & $\mathrm{kg} \cdot \mathrm{m}^{-3}$ & 1.6856 \\
1 & $\mathrm{mmho} / \mathrm{cm}$ & $\mathrm{dS} \cdot \mathrm{m}^{-1}$ & 1 \\
28.3495 & $\mathrm{oz}$ & $\mathrm{g}$ & 0.0353 \\
7.4892 & $\mathrm{oz} / \mathrm{gal}$ & $\mathrm{g} \cdot \mathrm{L}^{-1}$ & 0.1335 \\
0.001 & $\mathrm{ppm}$ & $\mathrm{g} \cdot \mathrm{L}^{-1}$ & 1000 \\
1 & $\mathrm{ppm}$ & $\mathrm{mg} \cdot \mathrm{L}^{-1}$ & 1 \\
6.8948 & $\mathrm{psi}$ & $\mathrm{kPa}$ & 0.1450 \\
$\left({ }^{\circ} \mathrm{F}-32\right) \div 1.8$ & ${ }^{\circ} \mathrm{F}$ & ${ }^{\circ} \mathrm{C}$ & $\left({ }^{\circ} \mathrm{C} \times 1.8\right)+32$
\end{tabular}


to the end of the study, were (mean \pm SD) as follows: temperature $20.4 \pm$ $0.9^{\circ} \mathrm{C}$, daily light integral $9.9 \pm 5.1$ $\mathrm{mol} \cdot \mathrm{m}^{-2} \cdot \mathrm{d}^{-1}$, and vapor pressure deficit $1.14 \pm 0.45 \mathrm{kPa}$.

Plant material and fertilizer TREATMENTs. 'Delta Premium Pure Yellow' pansy seedling plugs were transplanted into square, 4 -inch pots filled with soilless substrate (Fafard 1P; Sun Gro Horticulture, Agawam, MA) on 21 Oct. 2016. Plants were grown in a greenhouse on ebb-andflow benches $(150 \mathrm{~cm}$ length $\times 90 \mathrm{~cm}$ width $\times 4 \mathrm{~cm}$ height; MidWest GroMaster, St. Charles, IL) covered with commercial grade weed cloth (Weed FreePro Fabric; Du Pont, Wilmington, DE). A separate $70-\mathrm{L}$ water tank and submersible pump (NK-2; Little Giant, Oklahoma City, OK) were used for each bench. Plants were watered once daily with potable water. A $19 \mathrm{~N}-1.7 \mathrm{P}-5.4 \mathrm{~K}$ controlledrelease fertilizer (19-4-8 with micronutrients; Harrell's, Lakeland, FL) was incorporated at seven different rates $\left(0,1,2,3,4,6\right.$, and $\left.8 \mathrm{~g} \cdot \mathrm{L}^{-1}\right)$. The recommended incorporation rate for this fertilizer is 6.5 to $10 \mathrm{lb} / \operatorname{yard}^{3}(\approx 4$ to $\left.6 \mathrm{~g} \cdot \mathrm{L}^{-1}\right)$.

ABA SPRAY solutions. Stock solution of $\mathrm{s}-\mathrm{ABA}$, the biologically active isomer of ABA [10\% s-ABA (VBC-30101; Valent BioSciences Corporation, Long Grove, IL)] was diluted with a surfactant solution (Brij 98 Surfactant; Valent BioSciences Corporation). The final solution contained $1 \mathrm{~g} \cdot \mathrm{L}^{-1} \mathrm{ABA}$ and $0.1 \mathrm{mg} \cdot \mathrm{L}^{-1}$ surfactant. This concentration was chosen because previous studies indicated that this is an effective rate to induce chlorosis in pansy (Weaver and van Iersel, 2014). Half of the plants of each fertilization rate were sprayed with the ABA solution once all plants had reached a salable size, $45 \mathrm{~d}$ after transplanting. Control plants were sprayed with water with $0.1 \mathrm{mg} \cdot \mathrm{L}^{-1}$ surfactant.

Measurements. To monitor the effect of fertilizer rate and plant available nutrients, pore water electrical conductivity (EC) was measured at four different times during the study, using a sensor that measures the temperature, dielectric, and bulk EC of the substrate (WET-2; Delta-T Devices, Burwell, Cambridge, UK). Those data are used to calculate the pore water EC (Hilhorst, 2000). Leaf chlorophyll concentration index (CCI) was measured on uppermost fully expanded leaves using a leaf chlorophyll meter (CCM-200; Apogee Instruments). The CCI is closely, but not linearly, related to leaf chlorophyll concentrations (Parry et al., 2014). All plants were measured at $0,1,3,5,7,10$, and $15 \mathrm{~d}$ after spray treatment. Aboveground parts of all plants were harvested $15 \mathrm{~d}$ after spray treatment. Samples were dried in a drying oven at $80^{\circ} \mathrm{C}$ for $4 \mathrm{~d}$ and then weighed.

STATistics. Plants were arranged in a randomized complete-block design with three replications. Each experimental unit had eight plants. Statistical analysis of pore water EC and leaf CCI was performed using repeated measures analysis of variance [ANOVA (SAS version 9.2; SAS Institute, Cary, NC). In the case of a significant $\mathrm{ABA}$-treatment $\times$ fertilizer interaction (i.e., CCI), the slice option of SAS was used to test for differences between the ABA-treated and control plants at each fertilization rate (SAS Institute, 2010). Dry weights were analyzed using ANOVA (SAS version 9.2). Plant responses to different fertilizer rates were analyzed using nonlinear regression (SigmaPlot 11.0; Systat Software, San Jose, CA).

\section{Results and discussion}

Pore water EC. Pore water EC of the substrate was similar on all four sampling dates and unaffected by ABA application. Pore water EC increased nonlinearly with increasing fertilizer rates, from $1 \mathrm{dS} \cdot \mathrm{m}^{-1}$ without any fertilizer to $\approx 3.2 \mathrm{dS} \cdot \mathrm{m}^{-1}$ with a fertilizer rate of $8 \mathrm{~g} \cdot \mathrm{L}^{-1}[P<$ 0.0001 (Fig. 1)]. This increase in EC was expected since increased fertilizer rates result in higher nutrient ion concentrations in the solution, detected by the pore water EC readings. Similarly, Klock-Moore and Broschat (1999) saw an increase in leachate EC with increasing controlled-release fertilizer rates and little change in leachate EC over time.

LEAF CHLOROPHYLL. There was a significant interactive effect of ABAtreatment $\times$ fertilizer rate $(P=0.03)$ and a main effect of measurement day on the leaf CCI $(P<0.0001)$. Leaf CCI increased near the end of the study and was 6.6 higher on the last than on the first measurement day, regardless of ABA or fertilizer treatment. The application of ABA significantly decreased leaf CCI below the levels of the control plants in the 2,4 ,

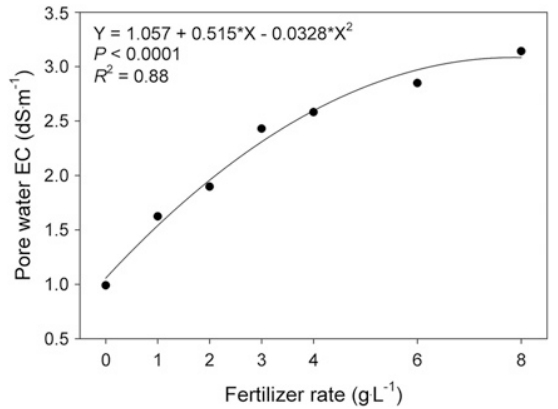

Fig. 1. Pore water electrical conductivity (EC) of the substrate, as affected by the rate of controlledrelease fertilizer. Data are averaged over four measurement dates and treatments with and without abscisic acid application $(\mathrm{n}=3) ; 1 \mathrm{~g} \cdot \mathrm{L}^{-1}=0.1335 \mathrm{oz} / \mathrm{gal}$, $1 \mathrm{dS} \cdot \mathrm{m}^{-1}=1 \mathrm{mhho} / \mathrm{cm}$.

6 , and $8 \mathrm{~g} \cdot \mathrm{L}^{-1}$ fertilizer treatments. A similar, but nonsignificant trend was seen at the other fertilizer levels (Fig. $2)$. This is consistent with previous findings that exogenous ABA spray applications cause chlorosis in pansy (Waterland et al., 2010a, 2010b; Weaver and van Iersel, 2014). Leaf CCI increased asymptotically with fertilization rate in both the control and ABA-treated plants $[P<0.0001$ (Fig. 2)]. Nitrogen and other nutrient deficiencies are well known to cause leaf chlorosis (Marschner, 2012), so the increase in CCI with increasing fertilizer levels is expected.

The extent of ABA-induced leaf chlorosis in this study was less than that has been previously observed with pansy (Waterland et al., 2010a, 2010 b; Weaver and van Iersel, 2014). This study differs from previous research that reported more severe chlorosis at similar rates of $\mathrm{ABA}$ because controlled-release fertilizer was used, whereas in earlier experiments plants were fertigated daily (Waterland et al., 2010a, 2010b; Weaver and van Iersel, 2014). However, the use of controlled-release fertilizer resulted in a stable pore water EC over the course of the study, suggesting a steady nutrient supply for the plants. It thus seems unlikely that the use of controlled-release fertilizer reduced the severity of the chlorosis.

SHOOT DRY WEIGHT. Final shoot dry weight was affected by fertilizer rate and $\mathrm{ABA}$ application, but not by their interaction. At all fertilization rates, $\mathrm{ABA}$ spray treatment reduced 




Fig. 2. Leaf chlorophyll concentration index of 'Delta Premium Pure Yellow' pansy grown with different controlled-release fertilizer rates in a peat:perlite substrate. Plants were sprayed with a $1 \mathrm{~g} \cdot \mathrm{L}^{-1}$ abscisic acid (ABA) solution or with water (no ABA). * indicates significant differences between control and ABAtreated plants within a specific fertilizer rate $(P<0.05, \mathrm{n}=3)$. Data are averaged over seven measurement days; $1 \mathrm{~g} \cdot \mathrm{L}^{-1}=0.1335 \mathrm{oz} / \mathrm{gal}$.

the shoot dry weights by $\approx 24 \%[P<$ 0.001 (Fig. 3)]. Similarly, Agehara and Leskovar (2015) reported that ABA sprays reduced root and shoot dry weight of bell pepper (Capsicum annuum) transplants. The ABAinduced reduction in dry matter accumulation is likely caused by restricted diffusion of $\mathrm{CO}_{2}$ into the leaf tissue due to ABA-induced stomatal closure (Buckley, 2005; Chaves et al., 2003; Pantin et al., 2012). Weaver and van Iersel (2014) previously showed that ABA spray applications reduce stomatal conductance and net photosynthesis of pansy in a rate-dependent manner for 2 weeks after application.

Within the ABA-treated and control groups, shoot dry weights were similar in all fertilized treatments ( 1.65 and $2.16 \mathrm{~g} /$ plant, respectively), but lower in the treatments without fertilizer (Fig. 3). This indicates that even the lowest fertilizer rate was sufficient to support maximal pansy shoot growth. Little information is available concerning controlledrelease fertilization rates in subirrigated ornamentals, because water-soluble fertilizers are typically used in subirrigation systems. Klock-Moore and Broschat (1999) showed that shoot growth of 'Ultra Red' petunia (Petunia $\times$ bybrida) and 'Super Elfin Violet' impatiens (Impatiens walleriana) increased linearly as controlled-release

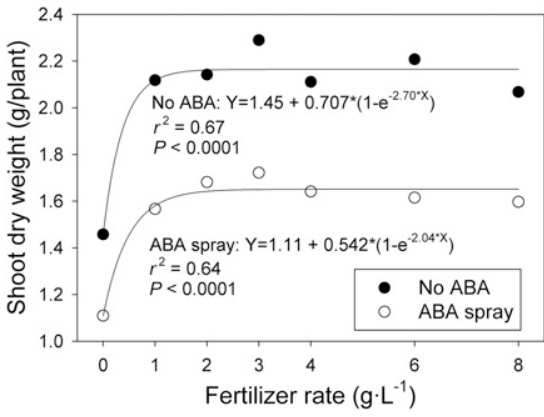

Fig. 3. Shoot dry weight of 'Delta Premium Pure Yellow' pansy grown under increasing fertilizer rates on peat:perlite substrate $(n=3)$. Plants were sprayed with a $1 \mathrm{~g} \cdot \mathrm{L}^{-1}$ abscisic acid (ABA) solution or with water; $1 \mathrm{~g} \cdot \mathrm{L}^{-1}=0.1335 \mathrm{oz} / \mathrm{gal}, 1 \mathrm{~g}=$ 0.0353 oz.

fertilizer rate increased from 1.25 to $7.5 \mathrm{~g} \cdot \mathrm{L}^{-1}$. Richards and Reed (2004) reported that dry weight of subirrigated 'Illusion' new guinea impatiens (Impatiens hawkeri) increased with increase in controlled-release fertilizer rates from 3.56 to $10.67 \mathrm{~g} \cdot \mathrm{L}^{-1}$, but decreased at higher rates. Thus, our finding that shoot dry weight of pansy was similar with fertilizer rates from 1 to $8 \mathrm{~g} \cdot \mathrm{L}^{-1}$ differs from previous findings. This may be related to differences among species, fertilizers, or environmental conditions in the various studies.

\section{Conclusions}

Spray applications of ABA lowered leaf CCI of pansy. Although higher fertilizer rates increased leaf CCI, they did not negate the effect of ABA sprays on CCI. Nonetheless, higher fertilizer rates could be used to mask the chlorosis induced by ABA applications. In addition to reducing chlorosis, ABA also reduced shoot dry weight by $24 \%$, regardless of the fertilizer application. The effect of ABA on dry weight cannot be negated by using higher fertilizer rates, since rates of 1 to $8 \mathrm{~g} \cdot \mathrm{L}^{-1}$ all resulted in similar shoot dry weights.

\section{Literature cited}

Agehara, S. and D.I. Leskovar. 2015. Growth suppression by exogenous abscisic acid and uniconazole for prolonged marketability of bell pepper transplants in commercial conditions. Sci. Hort. 194:118-125.

Buckley, T.N. 2005. The control of stomata by water balance. New Phytol. 168:275-292.
Chaves, M.M., J.P. Maroco, and J.S. Pereira. 2003. Understanding plant responses to drought from genes to the whole plant. Funct. Plant Biol. 30:239264.

Christmann, A., E.W. Weiler, E. Steudle, and E. Grill. 2007. A hydraulic signal in root-to-shoot signaling of water shortage. Plant J. 52:167-174.

Davies, W.J., G. Kudoyarova, and W. Hartung. 2005. Long-distance ABA signaling and its relation to other signaling pathways in the detection of soil drying and the mediation of the plant's response to drought. J. Plant Growth Regulat. 24:285-295.

Evans, J.R. 1983. Nitrogen and photosynthesis in the flag leaf of wheat (Triticum aestivum L.). Plant Physiol. 72:297302.

Galvez-Valdivieso, G., M.J. Fryer, T. Lawson, K. Slattery, W. Truman, N. Smirnoff, T. Asami, W.J. Davies, A.M. Jones, N.R. Baker, and P.M. Mullineaux. 2009. The high light response in Arabidopsis involves ABA signaling between vascular and bundle sheath cells. Plant Cell 21:2143-2162.

Hilhorst, M.A. 2000. A pore water conductivity sensor. Soil Sci. Soc. Amer. J. 64:1922-1925.

Kim, J. and M.W. van Iersel. 2011. ABA drenches induce stomatal closure and prolong shelf life of Salvia splendens. Sci. Hort. 127:420-423.

Kim, J., A. Malladi, and M.W. van Iersel. 2012. Physiological and molecular responses to drought in petunia: The importance of stress severity. J. Expt. Bot. 63:6335-6345.

Klock-Moore, K.A. and T.K. Broschat. 1999. Differences in bedding plant growth and nitrate loss with a controlledrelease fertilizer and two irrigation systems. HortTechnology 9:206-209.

Loh, F.C., J.C. Grabosky, and N.L. Bassuk. 2002. Using the SPAD 502 meter to assess chlorophyll and nitrogen content of benjamin fig and cottonwood leaves. HortTechnology 12:682-686.

Malladi, A. and J.K. Burns. 2007. Communication by plant growth regulators in roots and shoots of horticultural crops. HortScience 42:1113-1117.

Marschner, H. 2012. Marschner's mineral nutrition of higher plants. Academic Press, Waltham, MA.

Pantin, F., F. Monnet, D. Jannaud, J.M. Costa, J. Rennaud, B. Muller, T. Simonneau, and B. Gentry. 2012. The dual effect of abscisic acid on stomata. New Phytol. 197:65-72. 


\section{Research Reports}

Parry, C., J.M. Blonquist, and B. Bugbee. 2014. In situ measurement of leaf chlorophyll concentration. Analysis of the optical/absolute relationship. Plant Cell Environ. 37:2508-2520.

Raghavendra, A.S., V.K. Gonugunta, A. Christmann, and E. Grill. 2010. ABA perception and signalling. Trends Plant Sci. 15:395-401.

Richards, D.L. and D.W. Reed. 2004. New guinea impatiens growth response and nutrient release from controlledrelease fertilizer in a recirculating subirrigation and top-watering system. HortScience 39:280-286.

SAS Institute. 2010. SAS/STAT ${ }^{\circledR} 9.22$ user's guide. SAS Institute, Cary, NC.
Starman, T.W., S.E. Beach, and K.L. Eixmann. 2007. Postharvest decline symptoms after simulated shipping and during shelf life of 21 cultivars of vegetative annuals. HortTechnology 17:544551 .

van Iersel, M.W., K. Seader, and S. Dove. 2009. Exogenous abscisic acid application effects on stomatal closure, water use, and shelf life of hydrangea (Hydrangea macrophylla). J. Environ. Hort. 27:234-238.

Waterland, N.L., C.A. Campbell, J.J. Finer, and M.L. Jones. 2010a. Abscisic acid application enhances drought stress tolerance in bedding plants. HortScience 45:409-413.
Waterland, N.L., J.J. Finer, and M.L. Jones. 2010b. Benzyladenine and gibberellic acid application prevents abscisic acid-induced leaf chlorosis in pansy and viola. HortScience 45:925933.

Weaver, G.M. and M.W. van Iersel. 2014. Antitranspirational efficacy and longevity of abscisic acid and a synthetic abscisic acid analog in pansies (Viola $\times$ wittrockiana). HortScience 49:779784.

Yue, C. and B.K. Behe. 2008. Estimating U.S. consumers' choice of floral retail outlets. HortScience 43:764-769. 